\title{
The Effect of Dietary Administration of Virgin Coconut oil on Differential Leukocytes in Infected Chicken with Eimeria tenella
}

\author{
Zakia Sheila Faradilla ${ }^{1}$, Muchammad Yunus ${ }^{1 *}$, and Herry A. Hermadi ${ }^{2}$ \\ ${ }^{I}$ Department of Veterinary Parasitology, Faculty of Veterinary Medicine, Universitas Airlangga, Surabaya, East Java, Indonesia \\ ${ }^{2}$ Department of Veterinary Reproduction, Faculty of Veterinary Medicine, Universitas Airlangga, Surabaya, East Java, Indonesia \\ *Corresponding author's Email: muhyunus_99@yahoo.com, ORCID: 0000-0001-7516-6628
}

Received: 03 Nov. 2020

Accepted: 18 Dec. 2020

\begin{abstract}
Coccidiosis is the main problem in poultry diseases. It is caused by the parasite Eimeria tenella, which induce the immune response of leukocyte. Anticoccidial drugs are administered in the poultry feed to control coccidiosis. However, taking medication for a long time can lead to resistance. Recent studies have indicated that Virgin Coconut Oil (VCO) has some benefits, including anti-inflammatory effects. The present research aimed to identify the effect of VCO at the different doses in improving the various leukocyte counts of chickens infected with E. tenella. Male chickens were divided into five groups (T0, T1, T2, T3, and T4) and treated for 28 days. T0 was neither infected with $E$. tenella nor get treatment, T1 was only infected with E. tenella, T2 was treated with $5 \mathrm{ml} / \mathrm{kg} \mathrm{VCO}$ feed and had $E$. tenella infection, T3 was treated with $10 \mathrm{ml} / \mathrm{kg} \mathrm{VCO}$ feed and had E. tenella infection, and T4 was treated $20 \mathrm{ml} / \mathrm{kg}$ VCO feed and had E. tenella infection. Differential leukocyte was counted with a blood cell counter. The data obtained were analyzed using ANOVA and Duncan's Multiple Range Test. The results indicated that a dose of 10 $\mathrm{ml} / \mathrm{kg}$ feed and $20 \mathrm{ml} / \mathrm{kg}$ feed of VCO could improve the differential leukocyte counts of chickens infected with $E$. tenella by maintaining the counts of basophil, eosinophil, heterophil, monocyte, and lymphocyte in the normal range. The present study concluded that VCO by a dose of more than $10 \mathrm{ml} / \mathrm{kg}$ would improve the differential leukocyte counts of chickens infected with E. tenella.
\end{abstract}

Keywords: Differential leukocyte count, Eimeria tenella, Virgin Coconut Oil

\section{INTRODUCTION}

Coccidiosis caused by the parasite Eimeria tenella is the main problem facing poultry farmers. This parasite has a high virulence and multiplies intracellularly in the digestive tract of chicken caecum (Habibi et al., 2016; Fatoba and Adeleke, 2018). Coccidiosis is a disease caused by protozoa in a phylum of Aplicomplexa and genus Eimeria. Coccidiosis causes damage to the gastrointestinal tract and primarily affects domestic animals, wild animals, and poultry (Debbou-Iouknane et al., 2018; Dubey, 2018; Bachene et al., 2019). Although coccidiosis is a disease that was recognized long ago, the impact of economic loss because of it causing coccidiosis is becoming an important issue in society (Chapman, 2008; Debbou-Iouknane et al., 2018).

The economic loss caused each year by the coccidiosis in a poultry industry around the world reaches about US\$ one billion, due to the decrease in poultry performance and an increase in production cost (Berezin et al., 2010). Seven species of Eimeria (E. acervulina, E. brunetti, E. maxima, E. mitis, E. nectrix, E. praecox, and $E$. tenella) were known to be pathogenic in chickens (Chengat Prakashbabu et al., 2017), Among all Eimeria species, however, E. tenella is the most pathogenic species in which the predilection lies in the caecum and causes caecal coccidiosis (Muazu et al., 2008). Coccidiosis is controlled by adding anticoccidia to the feed (Pop et al., 2019). Recently, the usage of anticoccidia is still the main choice in the poultry industry as drugs administration is more effective than just depending on the poultry immune response (Alfaro et al., 2007; Pop et al., 2019). However, regular using of anticoccidial drugs over a long period of time had caused coccidian to become resistance to the drug, so the use of anti-coccidia and antibiotics must be reduced (Tipu et al., 2002).

There is a specific system in the body to eradicate various infectious and toxic materials. So, the immune system consisted of leukocyte (white blood cells) and tissue cells that derive from leukocyte. A disruption of the immune system leads to a change in the immune function, 
especially the cellular immune system such as leukocyte (Roeslan, 1996). Therefore, the leukocyte count of calculations can be used as one of the immune response indicators to determine if there is an infection in the body (Abdul Mohymen et al., 2014).

Virgin Coconut Oil (VCO) is a dietary supplement which can be produced by Indonesian coconut farmers in the home industry and is proved secure to be consumed by a human. Hence, it is believed that VCO can also be useful as a feed additive to be consumed by chickens (Attia et al., 2020). Recent studies have shown those VCO exhibits varying degrees of beneficial properties, such as antiviral, antibacterial, antifungal, anti-inflammatory, antipyretic, and antioxidant properties (Akinnuga et al., 2014). Virgin Coconut Oil (VCO) has proven to have a broad spectrum of antimicrobial activities against pathogenic microorganisms, including Gram-positive bacteria, i.e. S.aureus, Listeria monocytogenes, Streptococcus pyogenes, and Bacillus cereus; Gram-negative bacteria, i.e., Escherichia coli, Vibrio cholera and Salmonella Typhi and yeast, i.e. Candida albicans, C.krusei and Pityrosporumovale (Long, 1968).

In addition, a recent study on the effect of VCO against coccidiosis in broiler chicken indicated promising results and could be used as an alternative method to control coccidiosis in the poultry industry (Tan and Long, 2012). So, the objective of the present study was to evaluate the effect of VCO in improving the differential leukocyte count of broiler chicken infected with E. tenella.

\section{MATERIALS AND METHODS}

The present research used some equipment. There was chicken cage, feed and drink media, label, scale, media for gems, Slide, microscope, syringe, beaker glass, spuit, petri dish, cover dish, centrifuge, pipet, cover glass, and Blood Cell Counter.

The present research used Eimeria tenella from the Parasitology Department of Universitas Airlangga, DOC (Day Old Chick) strain Cobb from the chicken supplier in Surabaya, 14 days old chicken with Specific Antibody Negative (SAN), potassium dichromate (K2Cr2O7) 2.5\%, sugar solution $96 \%$, equates, Giemsa $10 \%$, distilled water, methanol and Virgin Coconut Oil (VCO) from Vico Bagoes by dr. Zainal Gani Jakarta.

\section{Ethical Approval}

Ethical regulations in the present study from the perspective of an animal breeder and researcher (chicken cage, feed drink media and handlings) were in according to "Bioethics of Poultry Production" (Macer, 2019).

\section{Activation and multiplication of Eimeria tenella} oocysts

Eimeria tenella isolate was activated by infecting five chickens at the age of two weeks that had never been infected by coccidiosis with 10,000 doses each. The chicken feces were collected on the seventh day after infection until the chickens were slaughtered on day tenth day. The feces were then mixed and placed in 2.5\% potassium dichromate $(\mathrm{K} 2 \mathrm{Cr} 2 \mathrm{O} 7)$ medium at room temperature $\left(28^{\circ} \mathrm{C}\right)$ for $24-48$ hours for the sporulation process, so that the infectous oocysts of E. tenella were obtained.

The sugar solution was mixed with the feces that has been speculated in the $2.5 \%$ potassium dichromate and placed in a beaker glass at the ratio of $1 / 1$. The solution was stirred until completely homogenous and then poured into a petri dish. After five minutes and the oocysts rose to the surface, the petri dish closed with the cover dish. After 30 minutes cover dish was lifted and washed with equivalents including distilled water. The oocyst suspension was then poured into a beaker glass. The isolation was done 5 to 6 times. The oocyst suspension, which still contained sugar, was washed with distilled water and centrifuged at $2500 \mathrm{rpm}$ for 5 to 10 minutes. This process was performed 3-4 times until the oocyst suspension became clear.

The oocysts count was performed using Haemositometer-Improved-Neubauer. The oocysts were observed and calculated under a microscope with 100x magnification. The calculation was made from the oocysts on four large squares in the corner of the courtroom. The number of oocysts from each milliliter suspension was therefore $2.5 \times 1000 \mathrm{n}=2500 \mathrm{n}$. The desired infection dose was prepared by diluting, so that each milliliter contained the required number of oocysts.

\section{Treatment of chickens}

The experimental unit that was used in the present study was healthy male Day-Old Chickens (DOCs) from a chicken supplier in Surabaya. The chickens' diets were standard feed for starter (0 to 7 days) and grower (8 to 34 days) diets, without coccidiostats additive (Tan and Long, 2012).

Samples of 30 DOCs were divided into five groups, the controlled negative (T0) group, the control positive (T1) group, the treatment I (T2) group, the treatment II (T3) group, and the treatment III (T4) group. In the control negative (T0) group, the chicken was not infected 
with E. tenella and was not treated with VCO. The chicken's cage was separated from the control positive (T1) group and treatment (T2, T3, and T4). In the control positive (T1) group the chicken was only infected with $E$. tenella at the age of 21 days old but was not treated with VCO. In the group of treatment I (T2), the chicken was treated with five $\mathrm{ml} \mathrm{VCO} / \mathrm{kg}$ feed from one day old chicken up to 28 days and infected with E. tenella at the age of 21 days old. In the group of treatment II (T3), the chicken was treated with $10 \mathrm{ml} \mathrm{VCO} / \mathrm{kg}$ feed from oneday old chick up to 28 days and infected with E. tenella at the age of 21 days old. In the group of treatment III (T4), the group was treated with $20 \mathrm{ml} \mathrm{VCO} / \mathrm{kg}$ feed from oneday old chick up to 28 days and infected with E. tenella at the age of 21 days.

\section{Blood sampling and smear preparation}

Blood sampling was done on hatch day, day three, and day six after infection. The blood was taken from the brachialis vein and then the blood smear was prepared. One drop of the chicken blood sample was anticoagulant in the first slide with a flat position. Then, the slide with blood sample was shifted using another sterile slide with an angel of $30^{\circ}$ so that it formed a thin layer of blood and it was dried at environment temperature. The blood smear was then soaked into methanol as a fixation within five minutes. The blood smear was dried at the environment temperature and then soaks into gems stain for 30 minutes. Thereafter, the blood smear was washed with water after staining, then the blood smear was placed vertically and allowed to dry again. Then a drop of Immersion oil was dropped on the blood smear and was observed under a microscope with $1000 \times$ magnification. The count started in the count area from the top left to bottom, then shifted to the right and then to the up and repeated until 100 cells of leukocyte were gotten based on the types using blood cell counter.

\section{Data analysis}

The design of the present research used completely randomized design. The data were analyzed by analysis of variance (ANOVA) and then followed by Duncan's Multiple Range Test to compare the treatment effect of each treatment.

\section{RESULTS}

The leukocytes count in each treatment group was performed from the blood smear. These five distinct leukocytes were basophil, eosinophil, heterophil, monocyte, and lymphocyte. The data on the leukocyte count were given as follows. The results of basophil count from the blood smear from E. tenella infected chicken that had been treated with VCO are presented in table 1 .

The data analysis of the VCO addition in the feed indicated that there was no significant difference ( $\mathrm{p}<$ 0.05) in the basophil count. The Duncan's Multiple Range Test indicated that the infected group had the highest decreasing amount of basophil among other groups on the day $6^{\text {th }}$ after infection. The $3^{\text {rd }}$ day after the infection group had the highest amount of basophil count and the highest number that could have got was from the T4 group with one basophil cell. The sixth day after the infection, infected group had less amount of the basophil and the lowest number that could have got was from the T1, T3, and T4 group with no basophil cell found. The results of eosinophils count from the blood smear of chicken treated with the VCO are presented in table 2.

Table 1. The result of the basophil count of the VCO effect in chicken infected with E. tenella

\begin{tabular}{lccc}
\hline \multirow{2}{*}{ Treatment } & \multicolumn{3}{c}{ Day after infection } \\
\cline { 2 - 4 } & $\mathbf{0}$ & $\mathbf{3}$ & $\mathbf{6}$ \\
\hline T0 & $0.50^{\mathrm{a}} \pm 1.00$ & $0.50^{\mathrm{a}} \pm 0.58$ & $0.25^{\mathrm{a}} \pm 0.50$ \\
T1 & $0.75^{\mathrm{a}} \pm 0.96$ & $0.75^{\mathrm{a}} \pm 0.50$ & $0.00^{\mathrm{a}} \pm 0.00$ \\
T2 & $0.25^{\mathrm{a}} \pm 0.50$ & $0.50^{\mathrm{a}} \pm 0.58$ & $0.25^{\mathrm{a}} \pm 0.50$ \\
T3 & $0.25^{\mathrm{a}} \pm 0.50$ & $0.25^{\mathrm{a}} \pm 0.50$ & $0.00^{\mathrm{a}} \pm 0.00$ \\
T4 & $0.50^{\mathrm{a}} \pm 0.58$ & $1.00^{\mathrm{a}} \pm 1.15$ & $0.00^{\mathrm{a}} \pm 0.00$
\end{tabular}

a: Means within a column with different superscripts differ significantly (p < 0.05). T0: negative control, T1: positive control or infected with $E$. tenella, T2: $5 \mathrm{ml} / \mathrm{kg}$ feed of VCO, T3: $10 \mathrm{ml} / \mathrm{kg}$ feed of VCO, T4: 20 $\mathrm{ml} / \mathrm{kg}$ feed of $\mathrm{VCO}$.

Table 2. The result of eosinophil count of the VCO effect in chicken infected with E. tenella

\begin{tabular}{lccc}
\hline \multirow{2}{*}{ Treatment } & \multicolumn{3}{c}{ Day after infection } \\
\cline { 2 - 4 } & $2.00^{\mathrm{b}} \pm 1.41$ & $3.50^{\mathrm{a}} \pm 2.08$ & $\mathbf{6}$ \\
\hline $\mathrm{T} 0$ & $4.25^{\mathrm{a}} \pm 1.50$ & $4.25^{\mathrm{b}} \pm 1.26$ \\
$\mathrm{~T} 1$ & $4.50^{\mathrm{a}} \pm 1.73$ & $4.50^{\mathrm{a}} \pm 1.00$ & $6.75^{\mathrm{a}} \pm 2.50$ \\
$\mathrm{~T} 2$ & $3.25^{\mathrm{ab}} \pm 0.50$ & $4.75^{\mathrm{b}} \pm 2.63$ & $1.00^{\mathrm{c}} \pm 1.29$ \\
$\mathrm{~T} 3$ & $3.50^{\mathrm{ab}} \pm 1.29$ & $4.75^{\mathrm{a}} \pm 1.26$ & $1.00^{\mathrm{c}} \pm 0.82$ \\
$\mathrm{~T} 4$ & \multicolumn{4}{c}{ b, c: Means } & within a column with different & superscripts differ \\
significantly (p $<0.05$ ). T0: negative control, T1: positive control or \\
infected with $E$. tenella, T2: $5 \mathrm{ml} / \mathrm{kg}$ feed of the VCO, T3: $10 \mathrm{ml} / \mathrm{kg}$ feed \\
of the VCO, T4: $20 \mathrm{ml} / \mathrm{kg}$ feed of the VCO.
\end{tabular}

The data in table 2 indicated that there was a significantly different $(p<0.05)$ among each group which increased in the third day and decreased in the sixth day after the infection. The third day after the infection, the infected groups which had the highest number of eosinophil were T3 and T4. Otherwise, the sixth day after the infection, the groups which had the less number of eosinophil were also T3 and T4. Although the T3 and T4 
Faradilla et al., 2020

were not significantly different from each other, they significantly different from other groups. T1 group was significantly different from the $\mathrm{T} 2$ group on the sixth day after infection. T1 group had the highest number of eosinophil among all groups on the day six after infection. Otherwise, T3 and T4 group had the lowest number of eosinophil among all other groups on the day six after infection. The results of heterophils count from the blood smear of chicken treated VCO are presented in table 3.

The data of table 3 presented that the T3 and T4 groups were significantly different $(\mathrm{p}<0.05)$ from all other groups, although $\mathrm{T} 3$ and $\mathrm{T} 4$ group were not significantly difference with each other. The highest number of heterophil on the third day after the infection was seen in the $\mathrm{T} 2$ group. The lowest number of heterophil on the sixth day after the infection was seen in the T4 group. The results of Monocytes count from the blood smear of chicken treated with the VCO are presented in table 4 .

The data had a significant difference $(\mathrm{p}<0.05)$ in the $\mathrm{T} 4$ group. The T1 group had the highest number of monocyte on the third day after infection, while the T4 group had the lowest number of monocyte on the third day after infection. The T4 group had the lowest number of monocyte on the sixth day after infection. The results of the lymphocyte count from the blood smear of chicken was treated with the VCO are presented in table 5.

The data of table 5 indicated significant difference ( $p$ $<0.05$ ) on the sixth day after the infection. The T4 group had the highest number of lymphocyte on the sixth day after infection, while the T3 group had the lowest number. The T2 and T3 groups showed significant difference at the beginning of the trial, the third, and the sixth day after infection. Although the T4 group showed a significant difference at the beginning of the trial and on the third day after infection, did not show any significant difference on the third and sixth days after infection. T1 group or control positive group showed a constantly decreasing number of lymphocytes, in contrast to other groups which showed an increasing number of lymphocytes.

Table 3. The result of the heterophil number of VCO effect in infected chicken with E. tenella infected chicken

\begin{tabular}{lccc}
\hline \multirow{2}{*}{ Treatment } & \multicolumn{3}{c}{ Day after infection } \\
\cline { 2 - 4 } & $13.75^{\mathrm{a}} \pm 2.22$ & $\mathbf{3}$ & $\mathbf{6}$ \\
\hline T0 & $12.00^{\mathrm{a}} \pm 2.94$ & $11.00^{\mathrm{a}} \pm 2.08$ & $7.75^{\mathrm{a}} \pm 1.50$ \\
$\mathrm{~T} 1$ & $13.25^{\mathrm{a}} \pm 2.22$ & $11.75^{\mathrm{a}} \pm 1.70$ & $7.00^{\mathrm{a}} \pm 2.16$ \\
T2 & $15.25^{\mathrm{a}} \pm 1.89$ & $4.00^{\mathrm{b}} \pm 1.41$ & $10.55^{\mathrm{a}} \pm 3.09$ \\
T3 & $13.75^{\mathrm{a}} \pm 2.63$ & $4.50^{\mathrm{b}} \pm 2.08$ & $6.75^{\mathrm{a}} \pm 2.50$ \\
T4 & \multicolumn{3}{c}{ a, b; Means within a column with different superscripts differ significantly } \\
(p < 0.05). T0: negative control; T1: positive control or infected with $E$.
\end{tabular}

tenella; $\mathrm{T} 2: 5 \mathrm{ml} / \mathrm{kg}$ feed of $\mathrm{VCO} ; \mathrm{T} 3: 10 \mathrm{ml} / \mathrm{kg}$ feed of $\mathrm{VCO} ; \mathrm{T} 4$ : $20 \mathrm{ml} / \mathrm{kg}$ feed of VCO.

Table 4. The result of monocyte count (\%) of the VCO effect in chicken infected with E. tenella

\begin{tabular}{lccc}
\hline \multirow{2}{*}{ Treatment } & \multicolumn{3}{c}{ Day after infection } \\
\cline { 2 - 4 } & $5.50^{\mathrm{ab}} \pm 1.91$ & $5.50^{\mathrm{b}} \pm 1.29$ & $\mathbf{3}$ \\
\hline $\mathrm{T} 0$ & $2.00^{\mathrm{c}} \pm 0.82$ & $8.25^{\mathrm{a}} \pm 2.06$ & $7.05^{\mathrm{a}} \pm 1.50$ \\
$\mathrm{~T} 1$ & $6.50^{\mathrm{ab}} \pm 2.08$ & $4.75^{\mathrm{b}} \pm 1.26$ & $7.75^{\mathrm{a}} \pm 3.09$ \\
$\mathrm{~T} 2$ & $7.75^{\mathrm{a}} \pm 2.50$ & $4.00^{\mathrm{b}} \pm 1.41$ & $10.50^{\mathrm{a}} \pm 1.73$ \\
$\mathrm{~T} 3$ & $4.50^{\mathrm{bc}} \pm 1.00$ & $4.50^{\mathrm{b}} \pm 2.08$ & $6.75^{\mathrm{a}} \pm 2.50$ \\
$\mathrm{~T} 4$ & $\mathrm{a}$, b, c; Means & within a column with different & superscripts differ \\
significantly (p < $<0.05)$. T0: negative control, T1: positive control or \\
infected with E. tenella, T2: $5 \mathrm{ml} / \mathrm{kg}$ feed of the VCO, T3: $10 \mathrm{ml} / \mathrm{kg}$ feed \\
of the VCO, T4: 20ml/kg feed of the VCO.
\end{tabular}

Table 5. The results of the lymphocyte count of the VCO effect in chicken infected with $E$. tenella

\begin{tabular}{|c|c|c|c|}
\hline \multirow{2}{*}{ Treatment } & \multicolumn{3}{|c|}{ Day after infection } \\
\hline & 0 & 3 & 6 \\
\hline T0 & $72.00^{b} \pm 3.74$ & $77.00^{\mathrm{a}} \pm 2.70$ & $79.75^{\mathrm{b}} \pm 0.50$ \\
\hline $\mathrm{T} 1$ & $80.00^{\mathrm{a}} \pm 5.71$ & $73.75^{\mathrm{a}} \pm 2.87$ & $73.75^{\mathrm{c}} \pm 2.87$ \\
\hline $\mathrm{T} 2$ & $75.50^{\mathrm{ab}} \pm 3.78$ & $78.50^{\mathrm{a}} \pm 2.08$ & $82.00^{\mathrm{b}} \pm 2.45$ \\
\hline $\mathrm{T} 3$ & $72.50^{\mathrm{b}} \pm 4.04$ & $76.75^{\mathrm{a}} \pm 4.35$ & $77.25^{\mathrm{bc}} \pm 5.73$ \\
\hline $\mathrm{T} 4$ & $77.75^{\mathrm{ab}} \pm 0.16$ & $75.25^{\mathrm{a}} \pm 4.19$ & $88.75^{\mathrm{a}} \pm 5.93$ \\
\hline
\end{tabular}

\section{DISCUSSION}

The average basophil count in each group was about zero to two percent or was still within the normal basophil range of one to four percent (Current et al., 1983), which proved that VCO was able to affect the amount of basophil. Basophil played the weakest role in the immune system (Tizard, 2013; Eberle and Voehringer, 2016), which is rarely found in the poultry blood under normal conditions. That is the reason for the low percentage of basophil in the total blood leukocytes.

The result also showed that the basophil increased on the third day after infection, possibly due to the fact that the basophil was stimulated at the inflammation site on the caecal epithelial caused by E. tenella. Basophil contains serotonin, heparin, and histamine that stimulate blood flow to the site of inflammation (Bijanti et al., 2010). Otherwise, the basophil decreased on the sixth day after infection, possibly because VCO acts as an antiinflammation substance (Sharifi-Rad et al., 2017). Virgin coconut oil has anti-inflammatory, moderate analgesic, and antipyretic properties (Intahphuak et al., 2010). It had been shown that fatty acids such as oleic and stearic acids in VCO attenuated the activity of polymorph nuclear 
leukocytes, which led to the suppression of inflammatory processes. It was suggested that the proportion of fatty acids integrated into membrane phospholipids affect membrane fluidity, which in turn could influence cell function (Zakaria et al., 2011). VCO had monolaurin and monocaprin substance, a monoglyceride substance that was used as anti-microbe, anti-viral, antibacterial, and antiprotozoal because they can dissolve the lipid-coated wall of the microbes, causing the cells of the microbes to rupture and die, so the amount of the parasites in the tissues and the amount of basophil would reduce (Arlee et al., 2013).

The data showed a significantly different $(\mathrm{p}<0.05)$ eosinophil counts. The data showed that the T3 and T4 group had the highest amount of increasing number of eosinophil on the third day after infection. Increasing numbers of eosinophils might be due to the VCO, which could help stimulate the immune system of the chicken. Even though eosinophil is most active during helminth parasite infection, some studies stated that the coccidian parasite could also lead to eosinophilia (Nutman, 2007). On the sixth day after infection, the most decreasing amount of eosinophil was observed in the T3 and T4 group. This might be because the VCO acted as an antiprotozoal and anti-inflammation, so the number of parasites in the tissues and the amount of eosinophil would decrease.

The normal range of eosinophil in the blood is about $2-8 \%$ of the total amount of leukocytes, so the number of eosinophil in the present research was still in the normal range. Eosinophil neutralize inflammatory factor released by mast cells and basophils in type 1 hypersensitivity reaction (Tizard, 2013). Eosinophil acts as a regulator of parasite infection by attaching to the parasite and releasing toxic substances to the parasite (Wen and Rothenberg, 2016). Eosinophil regulates the allergic reaction and acute inflammation, which can stimulate tissue damages (Jain, 1993).

It was known that eosinophils interact with homocytotropic antibodies ( $\operatorname{IgE}$ and $\operatorname{IgG})$, mast cells, and basophils. The antibody and $\mathrm{T}$ lymphocytes provided specificity for the reaction, and the IgE on mast cells attracted eosinophils to modulate the inflammatory reaction. The relative amounts of tissue $\operatorname{IgE}$, extractable histamine, and eosinophil suggested that these components form the immune system that was most pronounced on body surfaces, immunologically mediated, often parasitic related and frequently associated with eosinophilia (Ross et al., 1999).
The data in the table 3 indicate that there was a significant number of heterophilic differences $(p<0.05)$ between each day after infection, although there were still decreasing numbers of heterophil on the third and sixth days after infection. The results shown in the table 3 also announce that the average amount of heterophil tended to decrease constantly. A decrease in the amount of heterophil might be because heterophil has the opposite effect on lymphocytes called the $\mathrm{H} / \mathrm{L}$ ratio and this ratio is influenced by diseases and infection (or the stress hormones produced by infection) (Davis et al., 2008). It could also happen because VCO stimulated the host cellmediated immune system, which was done by lymphocyte $\mathrm{T}$.

Heterophiles could survive in tissues for one to two days. In the present study, however, the heterophiles decreased steadily for six days, possibly because VCO constantly helps reduce the inflammatory factors as was given to the chickens daily. Heterophile has most of the lysosomal enzymes, which are proteolytic enzymes used to digest bacteria and foreign protein materials (Guyton and Hall, 2006). Heterophiles find, digest, and kill foreign bodies and also acts as the first line of defense (Ganong and Ganong, 1995).

In table 3, the number of heterophile $(8.33 \%$ $11.67 \%$ ) was considered below the normal range $(20.9 \%$ or $25 \%-30 \%$ ) and reported as heteropenia. Heteropenia could be observed in the chicken infected with $E$. coli after three and six hours. Heteropenia or heterophilia in chickens could occurred with inflammation or infection, stress and sometimes neoplasia (DeRosa et al., 1992).

The data in table 4 indicate a significant difference in monocyte counts, although the T4 group had the lowest number of monocytes on the sixth day after infection, as VCO might reduce the oocyst in the chicken, which would lead to a decrease in the inflammatory factor. If the inflammatory factor is reduced, it also decreases the migration of monocytes to the caecal tissue. The reduction in the monocytes could indicate the healing process. The administration of VCO increased the secretion of thyroid hormone, which led to an increase in the metabolism process. If the metabolism increases, the cell function will be more efficient, which helps to protect the body from the bad condition and also accelerate the healing process (Boateng et al., 2016).

Monocytes are produced in the bone marrow about three to eight percent of the total leukocytes in the blood. Monocytes in poultry are the largest leukocytes with various forms from rounded to amoeboid shape. Compared to lymphocytes, the chromatin granules of the 
monocyte nucleus are less accumulated. Monocytes indicated phagocytic activity and migration into the tissues to become macrophages (Bijanti et al., 2010). Apart from the macrophage, monocytes are important to maintain the immune response by releasing glycoprotein regulators/monokines such as interferon, interleukin-l, hormone-like AMP (Adenosine Monophosphate), and active pharmacological substances such as prostaglandines and leukotrienes (Tizard, 1982).

The data in table 5 reveal significantly different $(\mathrm{p}<$ 0.05 ) lymphocyte counts, but the group treated with VCO indicated a more constant increase in lymphocyte count than the control negative group, and the T4 group had the most lymphocytes counts. It was known that palmitate and myristate acid in VCO are the phospholipid component of $\mathrm{T}$ lymphocytes. Therefore, VCO could stimulate lymphocytes and produce an antibody in the chickens (Gordon, 2003).

The $\mathrm{T}$ lymphocyte plays an important role in stimulating the immune system against certain diseases and stress factors. The $\mathrm{T}$ lymphocyte would react directly to antigen presented to the cell surface by an AntigenPresenting Cell (APC). The Th-CD4 interaction served to maintain the Th-APC binding intact during the specific antigen activation (Hussain et al., 2004). Lymphocyte Th would activate macrophages as a cellular immune response against infection with the intracellular pathogen (Gordon, 2003).

The result in table 5 shows that the T4 group had the highest lymphocyte counts, although the T3 had the lowest lymphocyte counts and the most stable increase in the lymphocyte counts. Possibly because VCO reduced the oocysts, so that the lymphocyte counts reduced. The stable increase could indicate the VCO function as an immunostimulant. The percentage range of lymphocyte count for T0-T3 was $75.5 \%$ to $82 \%$ or was still in the normal range of lymphocytes $(24 \%-84 \%$ of total leukocytes in the blood), but the T4 group on the sixth day after the infection indicated that the lymphocytes count was more than the normal range, possibly because the stress effect of the chicken or the $20 \mathrm{ml} / \mathrm{kg}$ feed dose of VCO had too much influence on the lymphocyte $\mathrm{T}$ production.

Eimeria tenella infection in chicken could cause the lymphocyte counts to reach $87 \%$ or exceed the normal range. The increase in the lymphocyte count could attributed to the effect of the inflammation of the caecaintestine (Patra et al., 2010). Chronic antigenic stimulation could lead to a greatly expanded circulating lymphocyte pool since the primary functions of the lymphocyte are immune response, humoral antibody production, and cellmediated immunity (Jones, 1999). Cell-mediated immunity plays an important role in protecting the chicken from coccidial infection.

There is increasing evidence that cell-mediated immunity plays a major role in resistance to infection, as $\mathrm{T}$ lymphocytes appear to respond to coccidial infection by both cytokine production and a direct cytotoxic attack on infected cells (Lillehoj and Trout, 1996; Yun et al., 2000).

\section{CONCLUSION}

The research result proved that adding Virgin coconut oil could improve the different leukocyte counts of chicken infected with $E$. tenella. The virgin coconut oil at the dose of $10 \mathrm{ml} / \mathrm{kg}$ feed as a dietary supplementation and 20 $\mathrm{ml} / \mathrm{kg}$ feed had the most significant result in improving the different leukocytes counts of the chicken infected with $E$. tenella. So, dietary ingestion of efficient vegetable oil especially Virgin coconut oil, regardless of efficient farming, could be useful in combating some parasitic diseases.

\section{DECLARATION}

\section{Authors' contribution}

All authors of manuscript; Z. Sheila Faradilla, Muchammad Yunus, and H.A. Hermadi had similar and continuous attempts in in vivo and in vitro experiments of present study.

\section{Competing interests}

The authors have declared there was no conflict of interest.

\section{Acknowledgments}

The authors thank the staff of the Faculty of Veterinary Medicine, Universitas Airlangga for supports and facilities.

\section{REFERENCES}

Abdul Mohymen N, Qader A, and Ad'hiah A (2014). Molecular Typing by Polymerase Chain Reaction Sequence Specific Primers (PCR- SSP) of Human Leukocyte Class I and Class II Alleles in a Sample of Iraqi Visceral Leishmaniasis Patients. International Journal of Advanced Biological and Biomedical Research, 2(8): 2412-2415. Available at: http://www.ijabbr.com/article_8440.html

Akinnuga AM, Jeje SO, Bamidele O, Amaku EE, Otogo FO, and Sunday VE (2014). Virgin coconut oil: Remedial effects on renal dysfunction in diabetic rats. Physiology Journal, 2014: 495926. DOI: https://doi.org/10.1155/2014/495926

Alfaro DM, Silva AVF, Borges SA, Maiorka FA, Vargas S, and 
Santin E (2007). Use of Yucca schidigera extract in broiler diets and its effects on performance results obtained with different coccidiosis control methods. Journal of Applied Poultry Research, 16: 248-254. DOI: https://doi.org/10.1093/japr/16.2.248

Arlee R, Suanphairoch S, and Pakdeechanuan P (2013). Differences in chemical components and antioxidant-related substances in virgin coconut oil from coconut hybrids and their parents. International Food Research Journal, 20(5): 2103-2109. Available http://www.ifrj.upm.edu.my/20\%20(05)\%202013/9\%20IFRJ \%2020\%20(05)\%202013\%20Pakdeechanuan\%20182.pdf

Attia YA, Al-Harthi MA, and Abo El-Maaty HM (2020). The Effects of different oil sources on performance, digestive enzymes, carcass traits, biochemical, immunological, antioxidant, and morphometric responses of broiler Chicks. Frontiers in Veterinary Science, 7: 181. DOI: https://doi.org/10.3389/fvets.2020.00181

Bachene MS, Temim S, Ainbaziz H and Bachene A (2019). Prevalence of rabbit coccidia in Medea Province, Algeria. World Veterinary Journal, 9(2): 123-128. Available at: http://wvj.scienceline.com/attachments/article/57/WVJ\%209(2)\%20123128,\%20June\%2025,\%202019.pdf

Berezin VE, Bogoyavlenskyi AP, Khudiakova SS, Alexuk PG, Omirtaeva ES, Zaitceva IA, Tustikbaeva GB, Barfield RC, and Fetterer RH (2010). Immunostimulatory complexes containing Eimeria tenella antigens and low toxicity plant saponins induce antibody response and provide protection from a challenge in broiler chickens. Veterinary Parasitology, 167: 28-35. DOI: https://doi.org/10.1016/j.vetpar.2009.09.045

Bijanti R, GandulAtikYuliani M, Wahjuni RS, and Utomo RB (2010). Veterinary Clinical Pathology Textbook. Airlangga University Press. Pp.53-107. Available at: https://www.wiley.com/enus/Fundamentals+of+Veterinary+Clinical+Pathology $\% 2 \mathrm{C}+2$ nd+Edition-p-9780813800769

Boateng L, Ansong R, Owusu W, and Steiner-Asiedu M (2016). Coconut oil and palm oil's role in nutrition, health, and national development: A review. Ghana Medical Journal, 50: 189-196. PMID: 27752194

Chapman HD (2008). Coccidiosis in the turkey. Avian Pathology, 37: 205-223. DOI: https://doi.org/10.1080/03079450802050689

Chengat Prakashbabu B, Thenmozhi V, Limon G, Kundu K, Kumar S, Garg R, Clark EL, Srinivasa Rao AS, Raj DG et al. (2017). Eimeria species occurrence varies between geographic regions and poultry production systems and may influence parasite genetic diversity. Veterinary Parasitology, 233: 62-72. https://doi.org/10.1016/j.vetpar.2016.12.003

Current WL, Reese NC, Ernst JV, Bailey WS, Heyman MB, and Weinstein WM (1983). Human cryptosporidiosis in immunocompetent and immunodeficient persons: studies of an outbreak and experimental transmission. The New England Journal of Medicine, 308: 1252-1257. DOI: https://doi.org/10.1056/nejm198305263082102

Davis AK, Maney DL, and Maerz JC (2008). The use of leukocyte profiles to measure stress in vertebrates: a review for ecologists. Functional Ecology, 22: 760-772. DOI: https://doi.org/10.1111/j.1365-2435.2008.01467.x

Debbou-Iouknane N, Benbarek H, and Ayad A (2018). Prevalence and aetiology of coccidiosis in broiler chickens in Bejaia province, Algeria. The Onderstepoort Journal of Veterinary Research, 85(1): e1-e6. DOI: https://doi.org/10.4102/ojvr.v85i1.1590

Dubey JP (2018). A review of coccidiosis in South American camelids. Parasitology Research, 117(7): 1999-2013. DOI: https://doi.org/10.1007/s00436-018-5890-y

DeRosa M, Ficken MD, and Barnes HJ (1992). Acute airsacculitis in untreated and cyclophosphamide-pretreated broiler chickens inoculated with Escherichia coli or Escherichia coli cell-free culture filtrate. Veterinary Pathology, 29: 68-78. DOI: https://doi.org/10.1177/030098589202900109

Eberle JU, and Voehringer (2016). Role of basophils in protective immunity to parasitic infections. Seminars in Immunopathology, 38: 605-613. DOI: https://doi.org/10.1007/s00281-016-0563-3

Fatoba AJ, and Adeleke MA (2018). Diagnosis and control of chicken coccidiosis: a recent update. Journal of Parasitic Diseases, 42: 483-493. DOI: https://doi.org/10.1007/s12639-018-1048-1

Ganong WF, and Ganong W (1995). Review of medical physiology. Appleton and Lange Norwalk, CT, UK. Pp.7083. Available at: https://emergencypedia.files.wordpress.com/2013/04/ganong -pdf.pdf

Gordon S (2003). Alternative activation of macrophages. Nature Reviews Immunology, 3: $23 . \quad$ DOI: https://wwww.doi.org/10.1038/nri978

Guyton AC, and Hall JE (2006). Textbook of medical physiology. $11^{\text {th }}$ edition. WB Saunders Company, Philadelphia. Pp.1002-1010. Availble at: https://www.amazon.com/Textbook-Medical-Physiology11th-Eleventh/dp/B002NAT0F6

Habibi H, Firouzi S, Nili H, Razavi M, Asadi L, and Daneshi S (2016). Anticoccidial effects of herbal extracts on Eimeria tenella infection in broiler chickens: in vitro and in vivo study. Journal of Parasitic Diseases, 40(2): 401-407. DOI: https://doi.org/10.1007/s12639-014-0517-4

Hussain MI, Khan SA, Chaudhary ZI, Aslam A, Ashraf K, and Rai MF (2004). Effect of organic and inorganic selenium with and without vitamin $\mathrm{E}$ on the immune system of broilers. Pakistan Veterinary Journal, 24: 1-4. Availble at: http://pvj.com.pk/pdf-files/24_1/1-4.pdf

Intahphuak S, Khonsung P, and Panthong A (2010). Antiinflammatory, analgesic, and antipyretic activities of virgin coconut oil. Pharmaceutical Biology, 48: 151-157. DOI: https://doi.org/10.3109/13880200903062614

Jain NC (1993). Essentials of veterinary hematology copyrights by Lea and Febiger, Philadelphia. Pp.1002-1036. Available at: https://www.semanticscholar.org/paper/Essentials-ofVeterinary-HematologyJain/d6fb81de5398593260f72bd9e665c10c678c53c4?p2df

Jones MP (1999). Avian clinical pathology. Veterinary Clinics of North America: Exotic Animal Practice, 2: 663-687. DOI: 


\section{https://doi.org/10.1016/s1094-9194(17)30115-9}

Lillehoj HS, and Trout JM (1996). Avian gut-associated lymphoid tissues and intestinal immune responses to Eimeria parasites. Clinical microbiology reviews, 9: 349360. PMID: $\underline{8809465}$

Long PL (1968). The pathogenic effects of Eimeria praecox and E. acervulina in the chicken. Parasitology, 58: 691-700. DOI: https://doi.org/10.1017/s0031182000028997

Macer D (2019). Ethical poultry and the bioethics of poultry production. The Journal of Poultry Science, 56(2): 79-83. DOI: https://doi.org/10.2141/jpsa.0180074

Muazu A, Masdooq AA, Ngbede J, Salihu AE, Haruna G, Habu AK, Sati MN, and Jamilu H (2008). Prevalence and identification of species of Eimeria causing coccidiosis in poultry within Vom, Plateau State, Nigeria. International Journal of Poultry Science, 7: 917-918. DOI: https://dx.doi.org/10.3923/ijps.2008.917.918

Nutman TB (2007). Evaluation and differential diagnosis of marked, persistent eosinophilia.

Immunology and Allergy Clinics of North America, 27: 529549. DOI: https://doi.org/10.1016/j.iac.2007.07.008

Patra G, Ali MA, Chanu KV, Jonathan L, Joy LK, Prava M, Ravindran R, Das G, and Devi LI (2010). PCR based diagnosis of Eimeria tenella infection in broiler chicken. International Journal of Poultry Science, 9: 813-818. DOI: $\underline{10.3923 / i j p s .2010 .813 .818}$

Pop LM, Varga E, and Coroian M (2019). Efficacy of a commercial herbal formula in chicken experimental coccidiosis. Parasites Vectors, 12: 343. DOI: https://doi.org/10.1186/s13071-019-3595-4

Roeslan BO (1996). Karakteristik Streptococcus mutans penyebab karies gigi (Characteristic Streptococcus mutans). Majalah Ilmiah Kedokteran Gigi FKG Usakti, 10: 112-113. Available at: https://scholar.google.co.id/scholar?oi=bibs\&cluster=74144 54324532419892\&btnI $=1 \&$ hl $=$ en

Ross TM, Oran AE, and Cullen BR (1999). Inhibition of HIV-1 progeny virion release by cell-surface CD4 is relieved by expression of the viral Nef protein. CurrentBiology, 9: 613621. DOI: $10.1016 / \mathrm{s} 0960-9822(99) 80283-8$

Sharifi-Rad J, Sureda A, Tenore GC, Daglia M, Sharifi-Rad M, Valussi M, Tundis R, Sharifi-Rad M, Loizzo MR, Ademiluyi AO et al. (2017). Biological activities of essential oils: from plant chemoecology to traditional healing systems. Molecules (Basel, Switzerland), 22(1): 70. DOI: https://doi.org/10.3390/molecules22010070

Tan GH, and Long K (2012). A preliminary study of the anticoccidial activity of medium-chain fatty acids (MCFA) and their corresponding monoglycerides on broiler chicken coccidiosis International Journal of Biotechnology for Wellness Industries, 1: 134-141. Available at: https://www.lifescienceglobal.com/pms/index.php/ijbwi/arti cle/download/36/101

Tipu MA, Pasha TN, and Ali Z (2002). Comparative Efficacy of Salinomycin Sodium and Neem Fruit (Azadirachta Indica). International Journal of Poultry Science1, Pp. 91-93. DOI: https://doi.org/10.3923/ijps.2002.91.93

Tizard I (1982). An introduction to veterinary immunology. Immunology and Allergy Clinics of North America, 27: 529549. DOI: https://doi.org/10.1111/j.1365-3164.2009.00733.x

Tizard IR (2013). Veterinary Immunology-E-Book. Elsevier Health Sciences. Pp.110-125. Available at: https://www.elsevier.com/books/veterinaryimmunology/tizard/978-1-4557-0362-3

Wen T, and Rothenberg ME (2016). The regulatory function of eosinophils. Microbiology Spectrum, 4(5): 10. DOI: https://doi.org/10.1128/microbiolspec.MCHD-0020-2015

Yun CH, Lillehoj HS, and Lillehoj EP (2000). Intestinal immune responses to coccidiosis. Developmental and Comparative Immunology, 24: 303-324. DOI: https://doi.org/10.1016/s0145-305x(99)00080-4

Zakaria ZA, Somchit MN, Jais AMM, Teh LK, Salleh MZ, and Long K (2011). In vivo antinociceptive and antiinflammatory activities of dried and fermented processed virgin coconut oil. Medical Principles and Practice, 20: 231236. DOI: https://doi.org/10.1159/000323756 